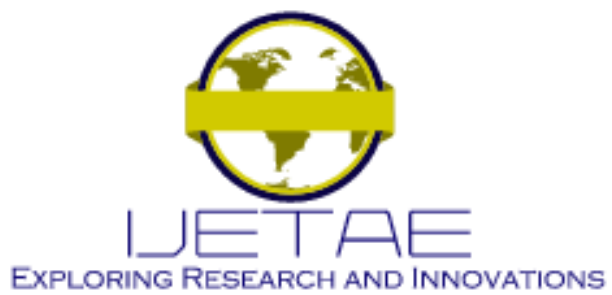

International Journal of Emerging Technology and Advanced Engineering

Website: www.ijetae.com (E-ISSN 2250-2459, Scopus Indexed, ISO 9001:2008 Certified Journal, Volume 11, Issue 08, August 2021)

\title{
Prediction of Earnings Manipulation on Malaysian Listed Firms: A Comparison between Linear and Tree-based Machine Learning
}

\author{
Rahayu Abdul Rahman ${ }^{1}$, Suraya Masrom ${ }^{2}$, Nor Balkish Zakaria ${ }^{3}$, Enny Nurdin ${ }^{4}$, Abdullah Sani Abd Rahman ${ }^{5}$ \\ ${ }^{1,4}$ Faculty of Accountancy, Universiti Teknologi Mara, Perak Branch, Tapah Campus, Malaysia. \\ ${ }^{2}$ Faculty of Computer and Mathematical Sciences, Universiti Teknologi Mara, Perak Branch, Tapah Campus, Malaysia. \\ ${ }^{3}$ Accounting Research Institute, Universiti Teknologi Mara, Selangor, Malaysia. \\ ${ }^{5}$ Faculty of Science and Information Technology, Universiti Teknologi PETRONAS, Perak, Malaysia
}

\begin{abstract}
Predicting the earning manipulation is an inseparable part of financial-economic analysis, helping shareholders, investors, creditors and outsiders acquire high quality of firm's financial information. Thus, the aim of the paper is to compare the earnings manipulation prediction models developed by using two types of machine learning algorithms; linear and tree categories. The linear based machine learning are Logistic Regression and Generalized Linear Model while the tree based are Decision Tree and Random Forest. All of the algorithms were tested on dataset of earnings manipulation among 1874 firm-year observations of firms listed on Bursa Malaysia. The results indicate that the performances of the two kinds of machine learning is not extremely different except with the Decision Tree. Furthermore, the most outperformed algorithm has been presented by the linear based machine learning, which produced the best accuracy in the shortest total time completion. All the models present better ability in detecting the false cases of earnings manipulation rather than the true cases mainly from the tree based machine learning.
\end{abstract}

Keywords-- Earnings Manipulation, Earnings Management, Machine Learning, Malaysia.

\section{INTRODUCTION}

Earnings manipulation, widely known as earnings management has received much scholarly attention as such practices affect the quality and accuracy of financial information and accounting numbers. It is because earnings management is a practice of distorting the true financial position of business organisations and hides relevant information from investors and outsiders [1]. According to [2] earnings management is one of the managerial opportunism practices by management to meet their personal gains.
Such practices normally occurs when management manipulate firms financial statement and reported earnings using both cash or non cash accounting treatments.

Roychowdhury [3] stresses that management might use two methods in managing the reported earnings. First, firm's earnings can be managed using accruals accounting treatment, known as accruals earnings management (AEM). This manipulation of accounting numbers has no direct implication on cash flow of the firm. Example of AEM are management discretion or decisions on write down assets, recognize or defer revenues, capitalise or expense certain costs and time the adoption of new standards. Second, management might manage accounting numbers using real business activities, known as real earnings management (REM). REM affect cash flows of the firms as the managers manage earnings numbers using real economic actions. Examples of real activities manipulation including reductions in discretionary spending such as research and development (R\&D), reductions in advertising and maintenance expenditures, and aggressive price discounts to increase sales for the specified accounting period. A review of previous research on earnings management documented evidence that managers do manage earnings for a variety of reasons include to increase their compensation [4]-[8], reduce the probability of debt covenant default [9]-[13], avoid future political costs [14]-[17], avoid the negative stock price reaction [18]-[20] and lower the buyout price [21][22].

Given the significant impact of earnings management has stimulate academia interests to explore on the determinants of earnings management in order to identify factors that significantly affect such practices. 


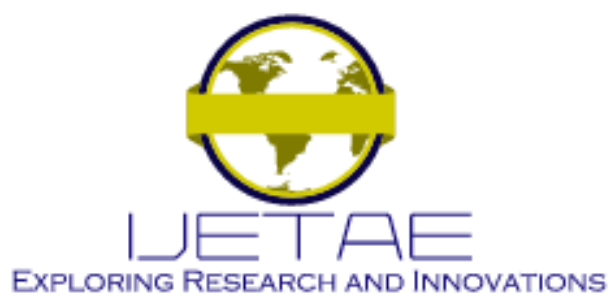

International Journal of Emerging Technology and Advanced Engineering Website: www.ijetae.com (E-ISSN 2250-2459, Scopus Indexed, ISO 9001:2008 Certified Journal, Volume 11, Issue 08, August 2021)

Tsai and Chiou [23] however argue that prior studies on this area more emphasis on the correlation between firm specific characteristic [24]-[27], corporate governance [28]-[31], ownership [32]-[35] as well as other factors [36][38] and earnings management, yet fail to examine the ability of these factors to signal earnings management. Thus, they stressed that it is important to construct earnings management prediction model using various factors to ensure firm's stakeholders receive accurate and reliable financial performance report. Motivated by the limitation, this paper aims to report the research works that employed different kinds of machine learning prediction models for the earning manipulation among Malaysian listed firms.

The growth of industrial 4.0 technologies results in increasing studies on the application of artificial intelligence in the finance, auditing and accounting literature. Previous research have highlight that machine learning and big data mining approaches are effective tools for financial prediction such as financial distress or bankruptcy [39]-[41], tax avoidance [42][43], tax fraud [44], and financial statement fraud [45][46]. In general, the results of prior studies show that accuracy of artificial intelligence method including via machine learning is greater than traditional statistical especially regarding nonlinear patterns [47]. Despite the wiser use of artificial intelligence methods in financial sector, research on earnings management prediction using such methods are limited [23][48]-[50].

In general the paradigm of machine learning is classified into two categories namely linear and tree based. Tree based machine learning has been said to has better performances than the linear paradigm in many cases [51]. However, the question raises in this research is how the accomplishment of these two types of machine learning on the tested dataset related to earning manipulation among the companies in Malaysia. Thus, the main purpose of this study is to extend the existing literature on earnings management by conducting a series of empirical experiments on different machine learning models of earnings manipulation prediction and further examining the effectiveness of the two machine learning paradigms.

This paper is organized as follows; Section 2 discusses on prior studies of earnings management prediction. Section 3 elaborates the research methodology in particular the dataset of earning manipulation and the machine learning specifications based on preliminary experiments.
Section 4 and section 5 presents the main findings and concludes the study respectively.

\section{LITERATURE REVIEW}

\section{A. Prior Research on Earnings Management Prediction}

The application of artificial intelligent techniques to evaluate the ability of financial and non financial factors on earnings management prediction began by [23]. The study uses 11 factors to predict earnings management using neural network. The results show that neural network prediction model on increasing accounting accrual generate 81 percent prediction rate. Further, [48] examines the utilization of 14 financial inputs in earnings management prediction models using Imperial Competitive Algorithm (ICA), Support Vector Machine (SVM) and Radial Bases Function (RBF) with combining Particle Swarm Optimization (PSO. Using 113 firms listed on Tehran Security Exchange, the findings show that earnings management prediction model by ICA has better performance than two other algorithms.

In addition, [49] aim to evaluate the effectiveness of Neural Network prediction model on earnings management using 12 influential factors among firms listed on Tehran Stock Exchange (TSE). The results indicate that the accuracy rates of the prediction model for the industries range between 81 percent; chemical product to 57 percent; non-metallic mineral product. More recent study by [50] investigates the ability of corporate governance features in signalling the earnings management activities of listed companies in Nigeria and Ghana. This study uses 4 corporate governance indexes as inputs for contructing $\mathrm{K}$ Nearest Neighbor (KNN) prediction model. In general, the results indicate that the $\mathrm{KNN}$ prediction rate are 68.63 percent and 75.37 percent for earnings management via real transactions and accruals respectively.

Furthermore, logistic regression and generalized linear model are two established prediction models that widely implemented with the machine learning paradigm. Different with conventional logistic regression and generalized linear model, the concept of training of datasets has been adopted to these methods, which also used in some application of earning managements [52]. Kim et al.[53] use machine learning logistic regression for the application of earnings management forecasting. 


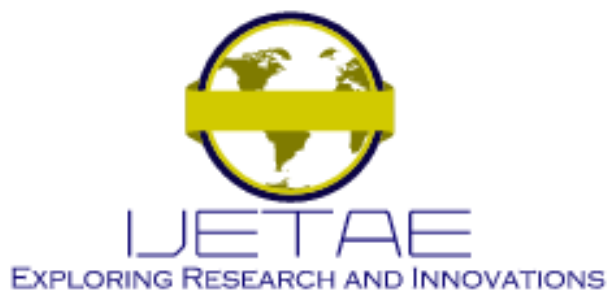

International Journal of Emerging Technology and Advanced Engineering

Website: www.ijetae.com (E-ISSN 2250-2459, Scopus Indexed, ISO 9001:2008 Certified Journal, Volume 11, Issue 08, August 2021)

Decision Tree and Random forest are categorized as tree based machine learning, which proved to have a number of advantages relative to the logistic and linear models [54]. These two machine learning can perform better than the linear based algorithm with a large dataset and also been used in the prediction of earning managements [55].

\section{RESEARCH METHOD}

\section{A. Data Collection}

The sample for this study consists of 1874 firm-year observations of public listed companies in Malaysia. Data for this study are collected from two sources; annual reports of the firms trace via Bursa Malaysia website and Thompson Reuters Datastream.

\section{B. Definition of Variables/Features}

In order to examine accrual earnings management (AEM) practices among Malaysian listed firms, one method of AEM has been chosen, known as income increasing discretionary accounting accrual. Following [56], this study estimates income increasing discretionary accrual using Modified Jones Model (MJM). In particular, income increasing discretionary accrual that signal manager's manipulation by earnings upwards is the positive residual value of the following model:

$\mathrm{TA}_{\mathrm{it}} / \mathrm{A}_{\mathrm{it}-1}=\alpha_{0}\left[1 / \mathrm{A}_{\mathrm{it}-1}\right]+\beta_{1}\left[\left(\Lambda \mathrm{REV}_{\mathrm{it}}-\Lambda \mathrm{REC}_{\mathrm{it}}\right) / \mathrm{A}_{\mathrm{it}-1}\right]+$ $\beta_{2}\left[\mathrm{PPE}_{\mathrm{it}} / \mathrm{A}_{\mathrm{it}-1}\right]+\varepsilon_{\text {it }}$

Where, $\mathrm{TA}_{\mathrm{it}}$ represents firm's total accruals for the current year. $A_{i t-1}$ is firm's assets of prior accounting period and $\Lambda R E V_{i t}$ is changes of firm's revenues.
Meanwhile, $\Lambda \mathrm{REC}_{\mathrm{it}}$ measures changes in firm's receivables and $\mathrm{PPE}_{\mathrm{it}}$ represents total firm's tangible non current assets.. $\varepsilon_{i t}$ is a residual values signal the degree of AEM in the firms.

With regards to the independent variables or machine learning features, this study uses four firm-specific characteristic factors; SIZE is natural log of firm's assets, LEVERAGE is natural log of ratio of firm's liabilities to assets, GROWTH is ratio of firm's market values to book values and PROFIT is ratio of earnings before interest and taxation to firm's assets. This study also uses six corporate governance features; BODIND is composition of board independence members, MUSBOD is percentage of Muslim board members, BODSIZE is total of board members, ACIND is composition of the audit committee independence members, DUALITY is 1 if CEO is also chairman of the firm and 0 otherwise, $\mathrm{MUSCH}$ is 1 if a firm has Muslim chairman and 0 otherwise, BIG4 is 1 if a firm hire Big-4 audit firms as external auditor and 0 otherwise. In addition, there are five ownership features use to predict income increasing discretionary accrual namely MSWGOWN is proportion of Minority Shareholder Watchdog Group institutional ownership, STATEGOVOWN is proportion of shareholding belong to the state and federal government, FGNOWN is percentage of shareholding by foreign shareholders, DIROWN is percentage of shareholding by firm's board of directors and FAMOWN is proportion of shareholding belong to the family members of firm's chairman, CEO and board of directors.

Table 1

Features In The Dataset And The Correlation Of Each Independent Variable To Income Increasing Discretionary Accrual

\begin{tabular}{|c|c|}
\hline Machine Learning Features & Correlation Value \\
\hline SIZE & 0.4104 \\
\hline LEVERAGE & 0.1668 \\
\hline GROWTH & 0.0385 \\
\hline PROFIT & 0.0041 \\
\hline BODIND & 0.0127 \\
\hline BODSIZE & 0.1061 \\
\hline ACIND & 0.0453 \\
\hline DUALITY & 0.0430 \\
\hline MUSCH & 0.0872 \\
\hline MUSBOD & 0.1710 \\
\hline BIG4 & 0.0622 \\
\hline MSWGOWN & 0.0882 \\
\hline STATEGOVOWN & 0.1284 \\
\hline FGNOWN & 0.0460 \\
\hline DIROWN & 0.1420 \\
\hline FAMOWN & 0.0492 \\
\hline
\end{tabular}




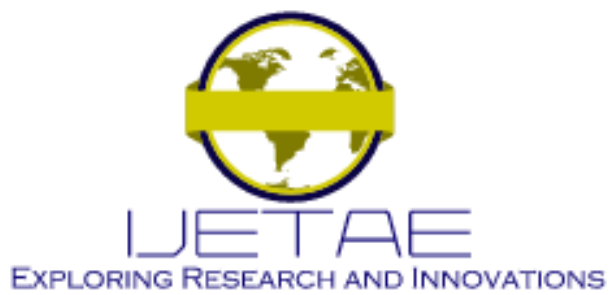

International Journal of Emerging Technology and Advanced Engineering

Website: www.ijetae.com (E-ISSN 2250-2459, Scopus Indexed, ISO 9001:2008 Certified Journal, Volume 11, Issue 08, August 2021)

\section{Machine Learning Experimental Setting}

The experiments were implemented with RapidMiner software in a notebook with 16GB RAM. Figure 1 is the flowchart that presenting the experimental processes.
This research applied two kinds of machine learning algorithms categorized as linear and tree based. Table 2 indicates two types of machine learning algorithms used in this study.

Table 2

Two Types Of Machine Learning Algorithms

\begin{tabular}{|c|c|}
\hline Linear based & Tree based \\
\hline Logistic Regression & Decision Tree \\
\hline Generalized Linear Model (GLM) & Random Forest \\
\hline
\end{tabular}

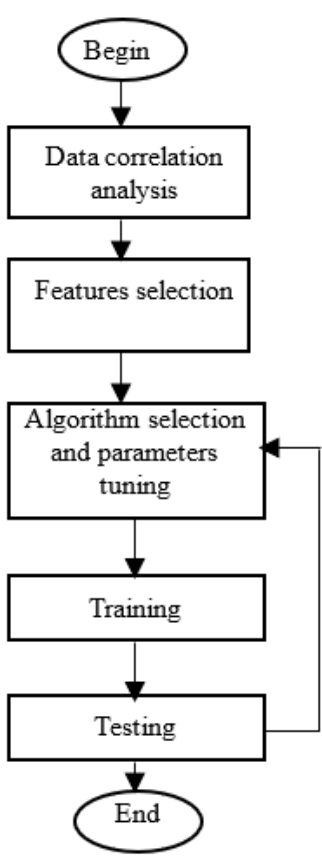

Figure 1 Flowchart Of The Machine Learning Implementation

Regardless of each category, the machine learning algorithms differ each other on the parameterization. For examples, Logistic Regression is a kind of Generalized Linear Model but each of them has different parameterization on function.
Logistic Regression parametrized by logit link function while GLM with link function.

Random Forest is an expansion of Decision Tree also by the parameterization different. Decision Tree generates only one tree model with maximal depth as the single parameter. On the other hand, Random Forest may has more than one tree and each tree has its respective depth. Preliminary empirical experiments have been conducted to identify the best parameter setting in the Decision Tree and Random Forest. Table 3 lists the percentages of error rate from the different values of maximal depth for Decision Tree.

Table 3

Different Values Of Decision Tree Parameter (Depth) With The Percentages Of Error Rate

\begin{tabular}{|c|c|}
\hline Maximal Depth & Error rate (\%) \\
\hline 2 & 44.9 \\
\hline 4 & 32.5 \\
\hline $\mathbf{7}$ & $\mathbf{2 9 . 4}$ \\
\hline 10 & 29.6 \\
\hline 15 & 30.4 \\
\hline
\end{tabular}

The optimal maximal depth for Decision Tree after 5 trials on the earnings managements dataset is 7 , which created the lowest error rate percentage (29.4\%). Furthermore, Table 4 lists different setting of Random Forest parameters and the percentages of error rate. 


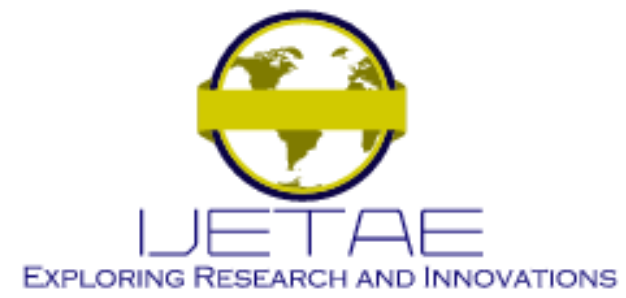

International Journal of Emerging Technology and Advanced Engineering Website: www.ijetae.com (E-ISSN 2250-2459, Scopus Indexed, ISO 9001:2008 Certified Journal, Volume 11, Issue 08, August 2021)

Table 4

Different Values Of Random Forest Parameters (Number Of Trees, Depth) With The Percentages Of Error Rate

\begin{tabular}{|c|c|c|}
\hline Number of Trees & Maximal Depth & Error Rate (\%) \\
\hline 20 & 2 & 31.2 \\
\hline 60 & 2 & 30.2 \\
\hline 100 & 2 & 30.0 \\
\hline 140 & 2 & 28.8 \\
\hline 20 & 4 & 29.4 \\
\hline 60 & 4 & 28.8 \\
\hline 100 & 4 & 29.2 \\
\hline 140 & 4 & 29.5 \\
\hline 20 & 7 & 28.4 \\
\hline 60 & 7 & 29.2 \\
\hline 100 & 7 & 29.2 \\
\hline 140 & 7 & \\
\hline
\end{tabular}

It has been observed from the 12 trials that the lowest error rate $(28.4 \%)$ was generated by 60 Number of Trees with 7 level of depth for the Random Forest. All the machine learning algorithms has been set to 70:30 ratio for dividing the training and testing segment from the earnings management dataset. Therefore, from the 1874 records, 1339 used for training and 535 for testing.

\section{Machine Learning performances evaluation}

Researcher can use many ways to measure the performances of machine learning classification models.

All the performance metrics can be calculated based on the confusion matrix. Figure 2 is an example of confusion matrix for this research.

\begin{tabular}{|c|c|c|c|}
\hline & & \multicolumn{2}{|c|}{ Predicted value } \\
\hline & & Positive earnings manipulation (1) & $\begin{array}{l}\text { Negative earnings } \\
\text { manipulation }(0)\end{array}$ \\
\hline \multirow[t]{2}{*}{ Actual value } & $\begin{array}{l}\text { Positive earnings } \\
\text { manipulation (1) }\end{array}$ & True Positive (TP) & False Negative (FN) \\
\hline & $\begin{array}{l}\text { Negative earnings } \\
\text { manipulation }(0)\end{array}$ & False Positive (FP) & True Negative (FN) \\
\hline
\end{tabular}

Figure 2 Confusion Matrix Of Earnings Manipulation

The income increasing earnings manipulation classification model is to predict either there is occurrence or non-occurrence cases denoted as 1 and 0 respectively. Refer to Figure 1, there are four scenarios of the prediction cases, which are:

- True Positive (TP) - The model correctly predict the occurrences of income increasing earnings manipulation.

- False Positive (FP) - The model wrongly predict nonoccurrence cases of income increasing earnings manipulation as 1 . This is type 1 error.
- False Negative $(F N)$ - The model incorrectly predict the occurrence cases of income increasing earnings manipulation as 0 . This is type 2 error.

- True Negative (TN) - The model correctly predict negative cases of income increasing earnings manipulation.

By using the four cases, the performance metrics are listed in Table 5. 


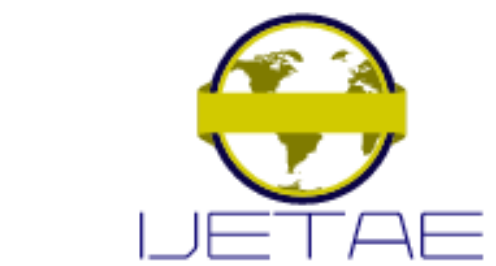

EXPLORING RESEARCH AND INNOVATIONS

International Journal of Emerging Technology and Advanced Engineering

Website: www.ijetae.com (E-ISSN 2250-2459, Scopus Indexed, ISO 9001:2008 Certified Journal, Volume 11, Issue 08, August 2021)

Table 5

Performance Metrics

\begin{tabular}{|l|l|l|}
\hline Metrics & Calcualtion & Description \\
\hline Accuracy & $(\mathrm{TP}+\mathrm{TN}) /(\mathrm{TP}+\mathrm{FP}+\mathrm{TN}+\mathrm{FN})$ & $\begin{array}{l}\text { The number of cases for both } 1 \text { and } 0 \text { predicted } \\
\text { correctly from the overall total cases. }\end{array}$ \\
\hline Classification Error & $(\mathrm{FP}+\mathrm{FN}) /(\mathrm{TP}+\mathrm{FP}+\mathrm{TN}+\mathrm{FN})$ & $\begin{array}{l}\text { The number of } 1 \text { and } 0 \text { cases predicted incorrectly } \\
\text { over all cases. }\end{array}$ \\
\hline Recall, Sensitivity & $\mathrm{TP} /(\mathrm{TP}+\mathrm{FN})$ & $\begin{array}{l}\text { The number of 1 cases successfully correctly } \\
\text { detected over the total actual } 1 \text { cases. }\end{array}$ \\
\hline Specificity & $\mathrm{TN} /(\mathrm{TN}+\mathrm{FP})$ & $\begin{array}{l}\text { The number of correct } 0 \text { cases successfully } \\
\text { predicted over the total actual } 0 \text { cases. }\end{array}$ \\
\hline Precision & $\mathrm{TP} /(\mathrm{TP}+\mathrm{FP})$ & $\begin{array}{l}\text { The number of } 1 \text { cases predicted correctly from } \\
\text { the total number of } 1 \text { cases. }\end{array}$ \\
\hline f-score & $(2 *$ Precision * Recall $) /($ Precision + Recall $)$ & The harmonic mean between precision and recall. \\
\hline
\end{tabular}

The specificity and sensitivity are negation to each other, means that lower specificity increases sensitivity. Area Under Curve (AUC) is an additional metrics used in this research, which can present the general performance of the classifier. The AUC presents the trade-off between True Positive Rate (TPR) and False Positive Rate (FPR) at different thresholds between 0 to 1 of the relative Receiver Operating Characteristics (ROC) graph.
Figure 3 is an example of ROC graph from this research. The AUC value that is above 0.85 indicates a good classification accuracy, value in range of 0.75 to 0.85 is called as moderate accuracy and less than 0.75 as low accuracy [57]. Compared to single accuracy measurement in Table 5, AUC is better measurement to present the overall model accuracy.

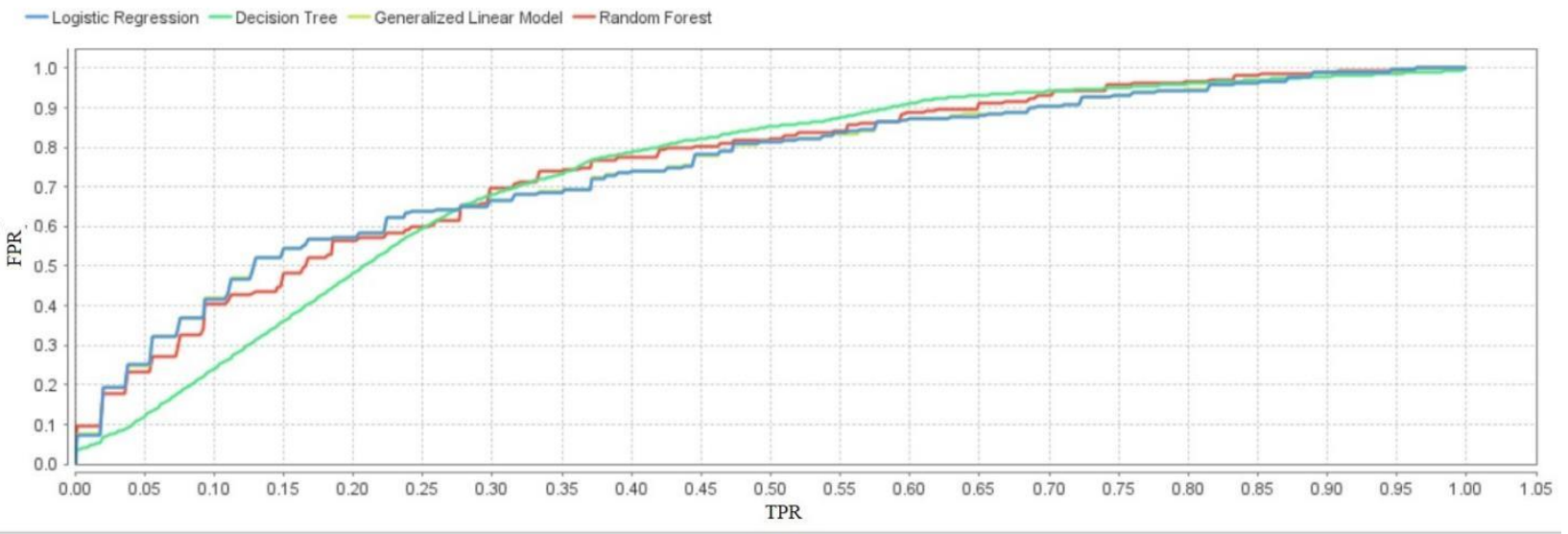

Figure 3 ROC Graph To Calculate AUC

\section{RESUlts And Discussion}

The results are divided in accordance to the linear and tree machine learning groups.
Table 6 is the results from the linear based machine learning algorithms. 


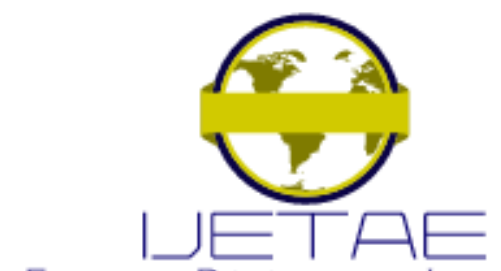

EXPLORING RESEARCH AND INNOVATIONS

International Journal of Emerging Technology and Advanced Engineering

Website: www.ijetae.com (E-ISSN 2250-2459, Scopus Indexed, ISO 9001:2008 Certified Journal, Volume 11, Issue 08, August 2021)

The Performances Results Of Linear Based Machine Learning

\begin{tabular}{|l|c|c|c|c|}
\hline & \multicolumn{2}{|c|}{ Logistic Regression } & \multicolumn{2}{c|}{ Generalized Linear Model } \\
\hline Metrics & Value & \pm Std.Dev. & Value & \pm Std.Dev. \\
\hline Accuracy & $68.8 \%$ & 2.2 & $68.8 \%$ & 2.2 \\
\hline Classification Error & $31.2 \%$ & 2.2 & $31.2 \%$ & 2.2 \\
\hline AUC & 0.748 & 0.027 & 0.748 & 0.027 \\
\hline Precision & $75.6 \%$ & 4.8 & $75.6 \%$ & 4.8 \\
\hline Recall & $54.9 \%$ & 6.2 & $54.9 \%$ & 6.2 \\
\hline f-score & $63.3 \%$ & 3.8 & $63.3 \%$ & 3.8 \\
\hline Sensitivity & $54.9 \%$ & 6.2 & $54.9 \%$ & 6.2 \\
\hline Specificity & $82.3 \%$ & 5.5 & $82.3 \%$ & 5.5 \\
\hline
\end{tabular}

Both linear based machine learning present a similar results of each metrics in predicting the earnings manipulation. Both algorithms have better ability on predicting the false cases of earnings manipulation, with specificity value $82.3 \%$.
Otherwise, they have $54.9 \%$ value (moderate) in detecting true cases of earnings manipulation. The performances of each linear based machine learning is better than tree based machine learning except on the specificity. Table 7 is the results from the tree based machine learning algorithms.

Table 7

The Performances Results Of Tree Based Machine Learning

\begin{tabular}{|l|c|c|c|c|}
\hline & \multicolumn{2}{|c|}{ Decision Tree } & \multicolumn{2}{c|}{ Random Forest } \\
\hline Criterion & Value & \pm Std.Dev & Value (\%) & \pm Std.Dev.(\%) \\
\hline Accuracy & $52.5 \%$ & 1.5 & $64.3 \%$ & 2.4 \\
\hline Classification Error & $47.5 \%$ & 1.5 & $35.7 \%$ & 2.4 \\
\hline AUC & 0.735 & 0.032 & 0.754 & 0.029 \\
\hline Precision & $78.3 \%$ & 21.7 & $78.0 \%$ & 2.9 \\
\hline Recall & $5.7 \%$ & 3.0 & $38.6 \%$ & 7.5 \\
\hline f-score & $10.4 \%$ & 5.3 & $51.3 \%$ & 6.4 \\
\hline Sensitivity & $5.7 \%$ & 3.0 & $38.6 \%$ & 7.5 \\
\hline Specificity & $98.2 \%$ & 1.8 & $89.3 \%$ & 3.1 \\
\hline
\end{tabular}

As seen in Table 7, Decision Tree has generated the lowest accuracy percentage but the highest specificity. The sensitivity of Decision Tree to detect the true cases of earnings manipulation is very low $(5.7 \% \pm 3.0)$.
To visualize the performances difference between all the machine learning models, Figure 4 and Figure 5 are the graphs for the results of accuracy and classification error. 


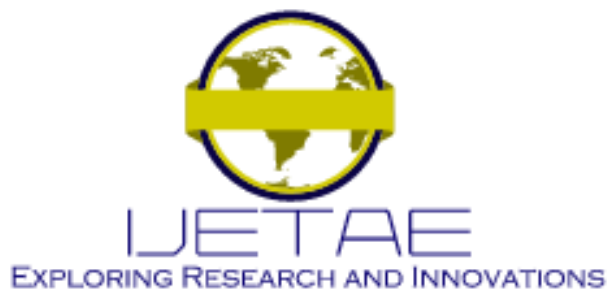

International Journal of Emerging Technology and Advanced Engineering

Website: www.ijetae.com (E-ISSN 2250-2459, Scopus Indexed, ISO 9001:2008 Certified Journal, Volume 11, Issue 08, August 2021)

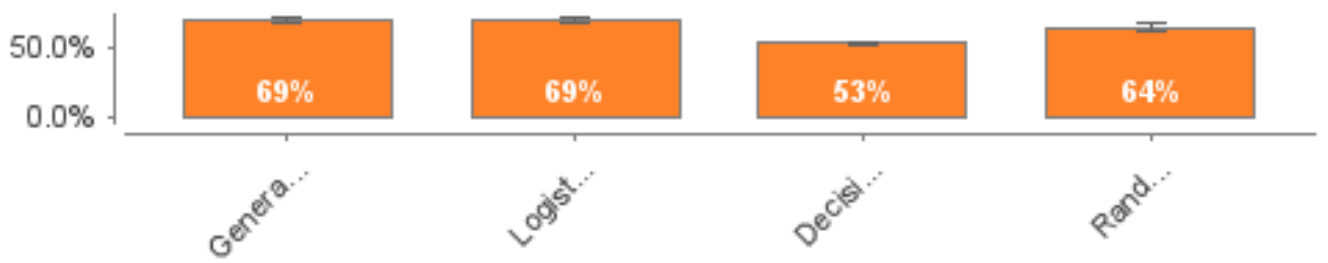

Figure 4 The Accuracy Of The Machine Learning Models

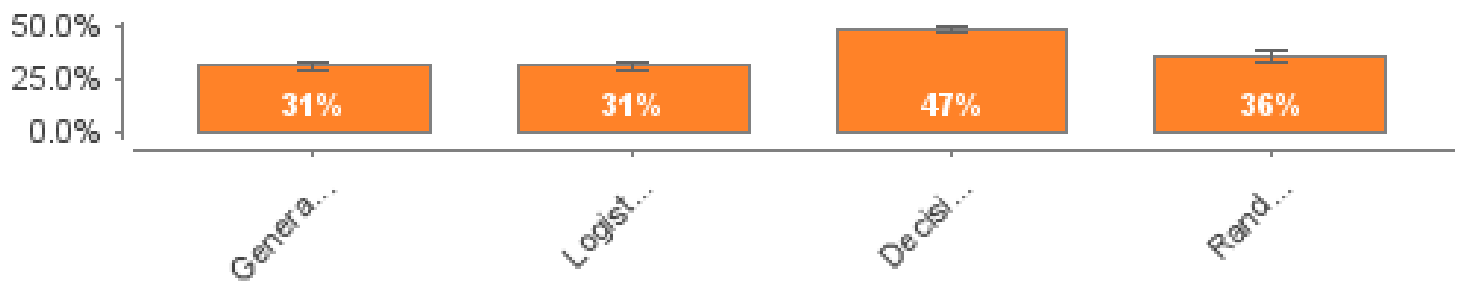

Figure 4 The Classification Error Of The Machine Learning Models

As expected, the Random Forest has taken a longer time to complete the prediction task due to the development of many trees (specified as 60) compared to the one tree in Decision Tree as listed Table 8.

Table 8

The Processing Time Of Each Machine Learning Algorithm

\begin{tabular}{|l|c|c|}
\hline & Total Time (second) & Training Time of 1000 rows (ms) \\
\hline Generalized Linear Model & 8 & 21 \\
\hline Logistic Regression & 7 & 23 \\
\hline Decision Tree & 7 & 21 \\
\hline Random Forest & 45 & 65 \\
\hline
\end{tabular}

The Random Forest took 65 milliseconds when tested on 1000 rows of training dataset and spend 45 seconds to complete the prediction.

\section{CONCLUSION}

The prediction of earnings management is still an issue of great importance. Thus, the purpose of this study is to predict the earnings management of listed firms in Malaysia. Despite the fact that the determinants of earnings management have been studied for a long time, the factors to predict such practice has not been found. The very limited number of research that predict earnings manipulation, motivated this investigation. For the empirical works, this research interested to look into the performances of different types of machine learning models on the tested dataset. Although tree based machine learning like Random Forest proved to be effective for the earnings manipulation model, but the performances is indistinguishable with the linear based machine learning.
Compared to linear based, Random Forest consumed much more time to complete. While Decision Tree can spend short time to complete like the linear based, the accuracy was not appealing. In spite of the contribution of this research, it is restricted by the small sample size that limit the generalisation of the results to other sectors mainly in business, management and financing. In the nearest future works, this study can be improved by an expansion of data that considering different input variables of the earnings manipulation model such as to consider the macroeconomic factors.

\section{Acknowledgement}

The authors acknowledge the financial support granted by the Accounting Research Institute, Universiti Teknologi MARA and Ministry of Higher Education, Malaysia for this project under $\mathrm{HICoE}$ grant. 


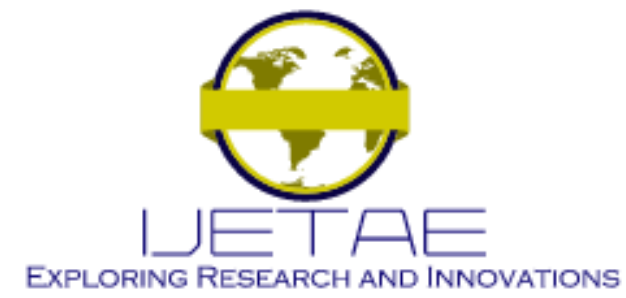

International Journal of Emerging Technology and Advanced Engineering Website: www.ijetae.com (E-ISSN 2250-2459, Scopus Indexed, ISO 9001:2008 Certified Journal, Volume 11, Issue 08, August 2021)

\section{REFERENCES}

[1] A. Klein, "Audit committee, board of director characteristics, and earnings management," Journal of accounting and economics, 33(3), 375-400, 2002.

[2] P. M. Healy, and J.M. Wahlen, "A review of the earnings management literature and its implications for standard setting," Accounting horizons, 13(4), 365-383, 1999.

[3] S. Roychowdhury, "Earnings management through real activities manipulation," Journal of accounting and economics, 42(3), 335370, 2006.

[4] M. Almadi, and P. Lazic, "CEO incentive compensation and earnings management," Management Decision, 2016.

[5] E. Bergstresser, and T. Philippon, "CEO incentives and earnings management," Journal of financial economics, 80(3), 511-529, 2006.

[6] M. Cornett, J. J. McNutt, and H. Tehranian, "Corporate governance and earnings management at large US bank holding companies," Journal of Corporate finance, 15(4), 412-430, 2009.

[7] P. M. Healy, "The effect of bonus schemes on accounting decisions," Journal of accounting and economics, 7(1-3), 85107,1985 .

[8] R.W. Holthausen, D.F. Larcker, and R. G. Sloan, "Annual bonus schemes and the manipulation of earnings," Journal of accounting and economics, 19(1), 29-74, 1995.

[9] S. D. Dyreng, S. A. Hillegeist, and F. Penalva, "Earnings management to avoid debt covenant violations and future performance," European Accounting Review, 1-33, 2020.

[10] B. Jaggi, and P. Lee, "Earnings management response to debt covenant violations and debt restructuring," Journal of Accounting, Auditing \& Finance, 17(4), 295-324, 2002.

[11] D. R. Franz, H. R. HassabElnaby, and G. J. Lobo, "Impact of proximity to debt covenant violation on earnings management," Review of Accounting Studies, 19(1), 473-505, 2014.

[12] B.H.Kim, L.L. Lisic, and M. Pevzner, "Debt covenant slack and real earnings management," Kertas kerja yang dipublikasikan melalui SSRN, 2010.

[13] A. Jha, "Earnings management around debt-covenant violations-An empirical investigation using a large sample of quarterly data" Journal of Accounting, Auditing \& Finance, 28(4), 369-396, 2013.

[14] M.B.R. Attia, N.Lassoued, and A. Attia, "Political costs and earnings management: evidence from Tunisia," Journal of Accounting in Emerging Economies, 2016.

[15] M. Al-Moghaiwli, "The Management of reported earnings to avoid political costs: a study of Saudi Arabian firms," International Journal of Management, 27(2), 254, 2010.

[16] D.Byard, M.Hossain, and S. Mitra, "US oil companies' earnings management in response to hurricanes Katrina and Rita," Journal of Accounting and Public Policy, 26(6), 733-748,2007.

[17] S.F.Cahan, "The effect of antitrust investigations on discretionary accruals: A refined test of the political-cost hypothesis," Accounting review, 77-95, 1992.

[18] W.R.Baber, S. Chen, and S.H. Kang, "Stock price reaction to evidence of earnings management: Implications for supplementary financial disclosure," Review of Accounting Studies, 11(1), 5-19, 2006.
[19] R. Kasznik, "On the association between voluntary disclosure and earnings management," Journal of accounting research, 37(1), 57-81, 1999.

[20] J.D.Gramlich, and O. Sørensen, "Voluntary management earnings forecasts and discretionary accruals: evidence from Danish IPOs," European Accounting Review, 13(2), 235-259, 2004.

[21] S.Lilien, B.Sarath, and Y.Yan, "Fair value accounting, earnings management, and the case of bargain purchase gain," Asian Review of Accounting, 2019.

[22] S.E.Perry, and T.H.Williams, "Earnings management preceding management buyout offers," Journal of Accounting and Economics, 18(2), 157-179,1994.

[23] C.F.Tsai, and Y.J. Chiou, "(2009). Earnings management prediction: A pilot study of combining neural networks and decision trees," Expert systems with applications, 36(3), 7183-7191, 2009.

[24] U. Uwuigbe, O.R. Uwuigbe, and B.Okorie, "Assessment of the effects of firms'characteristics on earnings management of listed firms in Nigeria," Asian economic and financial review, 5(2), 218$228,2015$.

[25] S.W.Bassiouny, "(2016). The impact of firm characteristics on earnings management: an empirical study on the listed firms in Egypt," Journal of Business and Retail Management Research, 10(3),2016.

[26] B.Alareeni, "The impact of firm-specific characteristics on earnings management: evidence from GCC countries," International Journal of Managerial and Financial Accounting, 10(2), 85-104,2018.

[27] N.Zamri, R.A.Rahman, and N.S.M.Isa, "The impact of leverage on real earnings management," Procedia Economics and Finance, 7, 8695,2013.

[28] Q.Liu, and Z.J.Lu, "Corporate governance and earnings management in the Chinese listed companies: A tunneling perspective," Journal of Corporate Finance, 13(5), 881-906, 2007.

[29] M.M.Cornett, A.J.Marcus, and H.Tehranian, "Corporate governance and pay-for-performance: The impact of earnings management," Journal of financial economics, 87(2), 357-373, 2008.

[30] J.S.González, and E. García-Meca, "Does corporate governance influence earnings management in Latin American markets?," Journal of business ethics, 121(3), 419-440, 2014.

[31] R.A.Rahman, N.H.Omar, A.H.Osman, A. H., \& M.Zakaria, "Do Big Four Auditors Limit Real Earnings Management?.,2020.

[32] R.A.Rahman, N.H. Omar, A. Rahman, and S. Kazemian, "Does shareholder activism limit real earnings management: Evidence of financial misreporting in family and foreign-owned business," International Journal of Economics and Management, 10(Special), 377-390,2016.

[33] S. Alves, "Ownership structure and earnings management: Evidence from Portugal," Australasian Accounting, Business and Finance Journal, 6(1), 57-74,2012.

[34] N.Lassoued, M.B.R. Attia, and H Sassi, "Earnings management and ownership structure in emerging market: Evidence from banking industry," Managerial Finance,2017.

[35] B.A.A.Ghaleb, H. Kamardin, and M.I.Tabash, "Family ownership concentration and real earnings management: Empirical evidence from an emerging market," Cogent Economics \& Finance, 8(1), 1751488,2020 . 


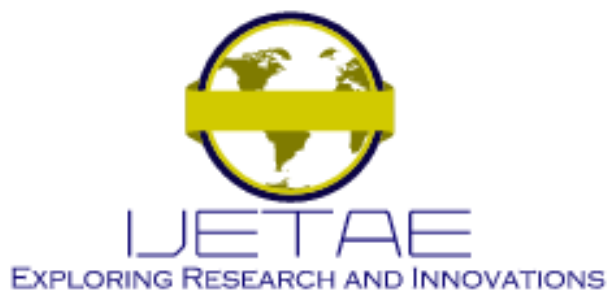

International Journal of Emerging Technology and Advanced Engineering Website: www.ijetae.com (E-ISSN 2250-2459, Scopus Indexed, ISO 9001:2008 Certified Journal, Volume 11, Issue 08, August 2021)

[36] R.A.Rahman, N.H.Omar, A. Rahman , and R. Muda, "Islamic ethical values of corporate top leadership and real earnings management," International Journal of Law and Management,2018.

[37] S.Buertey, E.J.Sun, J.S. Lee, and J. Hwang, "Corporate social responsibility and earnings management: The moderating effect of corporate governance mechanisms," Corporate Social Responsibility and Environmental Management, 27(1), 256-271,2020.

[38] O.Erin, and O.A. Bamigboye, "Does whistleblowing framework influence earnings management? An empirical investigation," International Journal of Disclosure and Governance, 17(2), 111-122, 2020.

[39] J.K.Bae, "Predicting financial distress of the South Korean manufacturing industries," Expert Systems with Applications, 39(10), 9159-9165,2012.

[40] C.H.Cheng, C. P.Chan, and Y.J. Sheu, "A novel purity-based k nearest neighbors imputation method and its application in financial distress prediction," Engineering Applications of Artificial Intelligence, 81, 283-299,2019.

[41] D.Liang, C .F. Tsai, H.Y.R.Lu, and L.S. Chang, “(2020). Combining corporate governance indicators with stacking ensembles for financial distress prediction," Journal of Business Research, 120, 137-146,2020.

[42] R.A.Rahman, S. Masrom, N., Omar, M., \& Zakaria, "An application of machine learning on corporate tax avoidance detection model," IAES International Journal of Artificial Intelligence, 9(4), 721,2020.

[43] R.A.Rahman, S. Masrom, and N. Omar, "Tax avoidance detection based on machine learning of malaysian government-linked companies," International Journal of Recent Technology and Engineering (IJRTE), 8,2019.

[44] N.D.Goumagias, D. Hristu-Varsakelis, and Y.M.Assael, "Using deep Q-learning to understand the tax evasion behavior of riskaverse firms," Expert Systems with Applications, 101, 258$270,2018$.

[45] J.Yao, J.Zhang, and L. Wang, "A financial statement fraud detection model based on hybrid data mining methods," In 2018 International Conference on Artificial Intelligence and Big Data (ICAIBD) (pp. 57-61). IEEE, 2018.

[46] P.Hajek, "Interpretable Fuzzy Rule-Based Systems for Detecting Financial Statement Fraud," In IFIP International Conference on Artificial Intelligence Applications and Innovations (pp. 425-436). Springer, Cham,2019.
[47] A.Bahrammirzaee, "A comparative survey of artificial intelligence applications in finance: artificial neural networks, expert system and hybrid intelligent systems," Neural Computing and Applications, 19(8), 1165-1195,2010.

[48] M.E.Ezazi, F.S. Ghotbi, and S.F. Ghotbi, "Predicting earning management using RBF, ICA, and SVM in firms listed in Tehran security exchange. Asian Journal Of Management Research, 4(1), 208-220,2013

[49] S.Mahmoudi, S. Mahmoudi, and A.Mahmoudi, "Prediction of earnings management by use of multilayer perceptron neural networks with two hidden layers in various industries," Journal of Entrepreneurship, Business and Economics, 5(1), 216-236, 2017.

[50] M.Wu, M., Coleman, and J. Bawuah, "The Predictive Power of KNearest Neighbor (KNN): The Effect of Corporate Governance Mechanisms on Earnings Management," SAGE Open, 10(3), 2020.

[51] J.Hunt, "Predicting Changes in Earnings: A Walk Through a Random Forest,'2018.

[52] J.Jiang, and T.Nguyen, "Linear and generalized linear mixed models and their applications," Springer Nature, 2021.

[53] K.Kim, S. Pandit, and C.E. Wasley, "Macroeconomic uncertainty and management earnings forecasts," Accounting Horizons, 30(1), 157-172,2016

[54] F.H.Chen, and H. Howard, "An alternative model for the analysis of detecting electronic industries earnings management using stepwise regression, random forest, and decision tree," Soft Computing, 20(5), 1945-1960,2016

[55] K.H.Hu, F. H. Chen, and W.J. Chang, "Application of correlationbased feature selection and decision tree to detect earnings management and accounting fraud relationship," ICIC Express Lett. Part B Appl, 2016.

[56] P.M. Dechow, R.G.Sloan, and A.P. Sweeney, "Detecting earnings management," Accounting review, 193-225,1995.

[57] A.J.Bowers, and X. Zhou, "Receiver operating characteristic (ROC) area under the curve (AUC): A diagnostic measure for evaluating the accuracy of predictors of education outcomes," Journal of Education for Students Placed at Risk (JESPAR), 24(1), 20-46, 2019 